\title{
ANALISIS SISTEM AKUNTANSI DAN PROSEDUR PEMBAYARAN KLAIM JAMINAN KEMATIAN PADA PT. TASPEN (PERSERO) CABANG MANADO
}

\author{
Fransher Dady ${ }^{1}$, Ventje Ilat ${ }^{2}$, Winston Pontoh ${ }^{3}$ \\ ${ }^{123}$ Jurusan Akuntansi, Fakultas Ekonomi dan Bisnis, Universitas Sam Ratulangi, J1. Kampus \\ Bahu, Manado, 95115, Indonesia \\ E-mail: anserdady@yahoo.com
}

\begin{abstract}
Insurance is one of the institutions that have an important role, because its activities play a role in risk protection, raising public funds from premium revenue. Guaranteed death (JKM) is one of the insurance that acts as a protection against the risk of death due to illness or work accidents in the form of death benefit. This study aims to determine the cash accounting system cash disbursements and payment procedures Claim for death (JKM) applied by PT. Taspen (Persero) Manado Branch Office. Type of research used in this research is descriptive research type qualitative approach. The results showed that the accounting system and payment procedures for death insurance claim applied to PT. Taspen (Persero) Manado Branch Office has been effective because it has been in accordance with the theory of cash accounting system expenditure, by comparing the cash accounting system expenditure applied by PT. Taspen (Persero) Branch Manado with the theory of cash accounting system expenditure.
\end{abstract}

Keywords: Cash Expenses, Payment Procedures, Death Warranty Claims

\section{PENDAHULUAN}

Asuransi merupakan salah satu lembaga yang memiliki peranan penting di Indonesia, karena kegiatannya berperan dalam perlindungan resiko, menghimpun dana masyarakat dari penerimaan premi. Jaminan kematian (JKM) merupakan salah satu asuransi yang berperan sebagai perlindungan atas resiko kematian akibat sakit atau kecelakan kerja berupa santunan kematian. http://www.taspen.co.id

Sistem adalah suatu kesatuan yang terdiri dari komponen atau elemen yang dihubungkan bersama untuk memudahkan aliran informasi. Setiap perusahaan memerlukan sistem yang baik di dalam menjalankan kegiatan perusahanya, selain itu sistem yang baik dapat digunakan sebagai dasar di dalam pengambilan keputusan, misalnya dengan menyajikan laporan keuangan yang relevan sehingga laporan keuangan tersebut bisa di percayai dan dapat digunakan oleh pihak intern maupun ekstern oleh karenanya setiap perusahaan dituntut untuk menerapkan sistem akuntansi yang sesuai dengan keadaan perusahaan. Penerapan Sistem Akuntansi dalam suatu perusahaan untuk mengatur jalannya semua aktifitas perusahaan yang bersifat operasional maupun non operasional sangatlah penting (Iniyati, 2013:1).

PT. Taspen (Persero) Kantor Cabang Manado adalah Badan Usaha Milik Negara (BUMN) yang merupakan perusahaan jasa yang salah satu tugasnya melayani transaksi pembayaran kepada peserta JKM (Jaminan Kematian) secara kas atau tunai maupun secara transfer atau dengan cek. Dalam melaksanakan pembayaran Jaminan Kematian PT. Taspen (Persero) Kantor Cabang Manado membutuhkan Sistem Akuntansi Pengeluaran Kas yang baik untuk mengendalikan kegiatan pembayaran jaminan kematian yang menghasilkan pengeluaran kas dengan cek tersebut agar sesuai dengan prosedur pengeluaran kas yang telah 
ditetapkan. Pada PT. Taspen (Persero) Kantor Cabang Manado terdapat masalah dimana dalam menjalankan proses bisnis sistem akuntansi pengeluaran kas terhambat dikarenakan ada beberapa kendala yang memperlambat pengolahan voucher dari bagian pelayanan ke bagian keuangan sehingga data yang tidak lengkap harus dikembalikan kepada peserta ahli waris untuk dilengkapi dan menyebabkan proses pembayaran tertunda sampai data tersebut lengkap dan siap untuk di proses. Penulis tertarik untuk melakukan penelitian pada PT. Taspen (persero) Kantor Cabang Manado dan mengangkat judul "Analisis Sistem Akuntansi dan Prosedur Pembayaran Klaim Jaminan Kematian pada PT. Taspen (Persero) Cabang Manado".

\section{TINJAUAN PUSTAKA}

\subsection{Akuntansi}

Akuntansi merupakan seni, ilmu, sistem informasi yang didalamnya menyangkut pencatatan, pengklasifikasian, dan pengikhtisaran dengan cara sepatutnya dan dalam satuan uang transaksi dan kejadian yang setidak-tidaknya sebagian mempunyai sifat keuangan serta adanya penginterpretasikan hasil pencatatan dan disajikan dalam laporan keuangan (Taswan, 2015:5).

\subsection{Akuntansi Manajemen}

Akuntansi manajemen adalah proses identiflkasi, pengukuran, akumulasi, analisa, penyiapan, penafsiran, dan komunikasi tentang informasi yang membantu masing-masing eksekutif untuk memenuhi tujuan organisasi (Charles T. Horngren, 1993:4)

\subsection{Sistem dan Prosedur}

Sistem adalah suatu jaringan prosedur yang dibuat menurut pola yang terpadu untuk melaksanakan kegiatan pokok perusahaan. Prosedur adalah suatu urutan kegiatan klerikal, biasanya melibatkan beberapa orang dalam satu departemen atau lebih yang dibuat untuk menjamin penanganan serta seragam transaksi perusahaan yang terjadi berulang-ulang (Mulyadi, 2013:5).

\subsection{Sistem Akuntansi}

Sistem akuntansi adalah organisasi formulir, catatan dan laporan yang dikoordinasi sedemikian rupa untuk menyediakan informasi keuangan yang dibutuhkan oleh menajemen guna memudahkan pengelola perusahaan (Mulyadi 2001:2).

\subsection{Pengertian Kas}

Kas merupakan aktiva lancar yang paling berharga bagi perusahaan karena sifatnya yang likuid. Semua transaksi bermula dan berakhir ke penerimaan kas atau pengeluaran kas, tanpa tersedianya kas yang memadai, perusahaan akan mengalami ksulitan dalam melakukan aktivitas sehari-hari. Akibatnya kegiatan atau aktivitas perusahaan akan terhambat dan tujuan tidak dapat dicapai (Weygandt, et al 2007: 462).

\subsection{Sistem Akuntansi Pengeluaran Kas}

Pengeluaran kas yaitu Suatu catatan yang dibuat untuk melaksanakan kegiatan pengeluaran baik dengan cek mapun dengan uang tunai yang digunakan untuk kegiatan umum perusahaan (Mulyadi, 2008:543).

Kaligis, Ilat, Pontoh (2015), pengendalian intern yang diciptakan dalam suatu perusahaan harus mempunyai beberapa tujuan. Sesuai dengan definisi yang dikemukakan oleh AICPA, maka dapatlah dirumuskan tujuan dari pengendalian intern, yaitu :

1. Menjaga keamanan harta milik perusahaan

2. Memeriksa ketelitian dan kebenaran data akuntansi

3. Memajukan efesiensi operasi perusahaan

4. Membantu menjaga kebijaksanaan manajemen yang telah ditetapkan lebih dahulu untuk dipatuhi 
5. Pemantauan, pemantauan harus dapat menilai kualitas kinerja dari waktu kewaktu dan memastikan bahwa rekomendasi hasil audit dan review lainnya dapat segera ditindaklanjuti.

\subsection{Asuransi}

Asuransi menurut pandangan bisnis, adalah sebuah perusahaan yang usaha utamanya menerima/menjual jasa, pemindahan risiko dari pihak lain, dan memperoleh keuntungan dengan berbagai risiko (sharing of risk) diantara sejumlah nasabahnya. Selain itu, asuransi juga merupakan lembaga keuangan bukan bank, yang kegiatannya menghimpun dana (berupa premi) dari masyarakat yang kemudian menginvestasikan dana itu dalam berbagai kegiatan ekonomi perusahaan (Darmawi, 2004:2).

\subsubsection{Manfat dan Tujuan Asuransi}

Purba (2002:6), dikutip dalam jurnal (Rosalie dan Budiarso, 2017), manfaat asuransi yaitu, sebagai berikut:

1. Mendorong masyarakat untuk lebih berpikir kemasa dating.

2. Dana yang terkumpul pada industry asuransi dapat digunakan untuk investasi yang digunakan dalam pembangunan.

3. Mendorong masyarakat untuk tidak tergantung pada pihak lain karena telah memiliki polis asuransi.

4. Ahli dari perusahaan asuransi dapat memberikan saran - saran untuk pengelolaan resiko dan mengurangi kemungkinan kerugian yang timbul.

Setiap perusahaan yang mengikuti program asuransi hanya perlu menyisikan sebagian kecil dananya untuk pembiayaan premi tanpa perlu membentuk cadangan dana untuk mengantisipasi kerugian yang timbul. Tujuan asuransi adalah untuk memberikan jaminan perlindungan resiko yang diderita suatu pihak, untuk meningkatkan efesiensi, untuk membantu mengadakan pemerataan biaya, untuk dasar pemberian kredit, sebagai tabungan, untuk memupuk earning power suatu perusahaan, dan untuk model investasi.

\subsection{Fungsi Asuransi Jiwa}

1. Alat atau Prasarana Menabung

Prasarana menabung artinya, sejumlah dana yang diasuransikan memiliki nilai tunai dan dapat diambil kembali, ini termasuk jenis asuransi tertentu seperti whole life atau endowment, ada jenis produk asuransi yang sengaja digabungkan dengan investasi, yaitu dinamakan unit link.

2. Memberikan Perlindungan atau Rasa Aman.

Dengan memiliki polis asuransi, pihak tertanggung akan terhindar dari kemungkinan timbulnya risiko kerugian di kemudian hari dan merasa aman dan tenang jiwanya karena objek yang diasuransikan telah dijaminan oleh penanggung polis.

3. Pengalokasian Biaya dan Manfaat yang Lebih Adil.

Semakin besar risiko kerugian yang timbul maka semakin besar pula premi pertanggungan dari pihak penanggung polis.

4. Memberikan Tingkat Kepastian.

Merupakan manfaat utama dari asuransi karena pada dasarnya mereka berusaha untuk mengurangi konsekuensi yang tidak pasti dari suatu keadaan yang merugikan, yang sudah diprediksikan sebelumnya sehingga biaya dari kerugian tersebut menjadi pasti atau relatif lebih pasti.

5. Membantu Meningkatkan Produktifitas Usaha Tertanggung

Tertanggung yang akan berinvestasi pada suatu bidang usaha tertentu (High Risk Business) bila sebagian resiko investasi tersebut dapat ditutup oleh asuransi untuk mengurangi resiko yang mungkin terjadi di kemudian hari.

6. Jaminan Kredit 
Polis asuransi dapat dijadikan sebagai jaminan pinjaman kredit, biasanya hanya untuk asuransi jiwa dan sangat selektif untuk jenis kredit dan bank tertentu.

\subsection{Jaminan Kematian (JKM)}

Jaminan kematian (JKM) merupakan salah satu asuransi yang berperan sebagai perlindungan atas resiko kematian akibat sakit atau kecelakan kerja berupa santunan kematian. http://www.taspen.co.id

\subsection{Penelitian Terdahulu}

1. Penelitian yang dilakukan oleh Sugiastuti, R. (2014), menunjukkan bahwa sistem dan prosedur pembayaran klaim kecelakaan pada PT.Jasa Raharja (Persero) Kantor Perwakilan Malang sebagian sudah mendukung dalam upaya meningkatkan pengendalian intern, namun ada beberapa yang belum mendukung pengendalian intern dan perlu dilakukan perbaikan.

2. Penelitian yang dilakukan oleh Iniyati, A. (2013), menunjukkan bahwa Sistem Akuntansi Pengeluaran Kas sudah sesuai dengan teori dan sudah efektif.

\section{METODE PENELITIAN}

\subsection{Jenis dan Sumber Data}

Jenis Penelitian yang digunakan dalam penelitian ini adalah jenis penelitian deskriptif pendekatan kualitatif. Penelitian dengan analisis data yang menggunakan metode deskriptif kualitatif yaitu metode penelitian dengan cara mengumpulkan data-data lalu akan dikelompokkan dan disusun agar dapat diteliti berdasarkan teori yang relevan serta berhubungan dengan masalah yang dibahas sehingga untuk kemudian dapat diambil atau ditarik suatu kesimpulan, dan peneliti juga menggunakan penelitian pada kondisi objek yang alamiah (Sugiyono, 2013:9).

Data kualitatif adalah data yang berbentuk kata-kata, bukan dalam bentuk angka. Data kualitatif diperoleh melalui berbagai macam teknik pengumpulan data misalnya wawancara, analisis dokumen, diskusi terfokus, atau observasi yang telah dituangkan dalam catatan lapangan. (Sugiyono, 2013:1)

Sumber Data Penelitian yang digunakan sebagai berikut:

1. Data Primer, adalah data yang diperoleh secara langsung dari objek yang diteliti, sumber primer adalah sumber data yang langsung memberikan data kepada pengumpul data (Sugiyono, 2010:137).

2. Data Sekunder, adalah data yang diperoleh dari buku - buku refrensi mengenai akuntansi, sejarah perusahaan, visi dan misi perusahaan, struktur organisasi perusahaan dan dokumen - dokumen lainnya yang berhubungan dengan penelitian ini (Sugiyono, 2013:308).

\subsection{Tempat dan Waktu Penelitian}

Penelitian ini dilaksanakan bertempat pada PT. Taspen (persero) Kantor Cabang Manado Jl. Ahmad Yani No. 07 Manado Sulawesi Utara, dengan waktu penelitian dimulai pada bulan Maret tahun 2017.

\subsection{Metode Analisis}

Penelitian ini menggunakan metode analisis kualitatif. Penelitian deskriptif meliputi penilaian sikap atau pendapat terhadap individu, organisasi, keadaan, ataupun prosedur. Data deskriptif pada umumnya dikumpulkan melalui daftar pertanyaan dalam survei, wawancara, ataupun observasi (Indrawan dan Yaniawati, 2014: 56).

\subsection{Prosedur Penelitian}

1. Persiapan Penelitian

Persiapan Penelitian dilakukan peneliti adalah membuat dan memasukkan surat pengajuan permohonan penelitian pada PT. Taspen (persero) Cabang Manado.

2. Pengumpulan Data 
Teknik pengumpulan data dalam penelitian ini adalah :

1. Wawancara

Wawancara, melakukan tanya jawab dengan pihak perusahaan mengenai datadata yang diperlukan.Wawancara merupakan pertemuan dua orang untuk bertukar informasi dan ide melalui tanya jawab, sehingga dapat dikontruksikan makna dalam suatu topik tertentu (Sugiyono, 2013:231).

2. Dokumentasi

Dokumentasi, meneliti setiap data-data yang diperoleh dari perusahaan melalui hasil wawancara. Dokumen merupakan catatan peristiwa yang sudah berlalu. Dokumen bisa berbentuk tulisan, gambar, atau karya-karya monumental dari seorang. Dokumen yang berbentuk tulisan misalnya catatan harian, sejarah kehidupan (life histories), ceritera, biografi, peraturan, kebijakan. Dokumen yang berbentuk gambar misalnya foto, gambar hidup, sketsa dan lain-lain. Dokumen yang berbentuk karya misalnya karya seni, yang dapat berupa gambar, patung, film dan lain-lain. Studi dokumen merupakan pelengkap dari penggunaan metode observasi dan wawancara dalam penelitian kualitatif (Sugiyono, 2013:240).

3. Analisis Data

Peneliti menganalisis keseluruhan data-data mengenai laporan keuangan yang telah didapat dari perusahaan asuransi yang menjadi objek penelitian dari peneliti maupun informasi yang didapat dari buku-buku, jurnal dan internet kemudian mengola seluruh data tersebut sesuai dengan teori yang dipelajari oleh peneliti.

4. Kesimpulan

Setelah pengumpulan data dan analisis data dilakukan maka peneliti membuat hasil penelitian sesuai dengan data yang didapat kemudian membuat kesimpulan dan saran untuk PT. Taspen (persero) Cabang Manado.

\section{HASIL PENELITIAN DAN PEMBAHASAN}

\subsection{Hasil Penelitian}

\subsubsection{Gambaran Umum Perusahaan}

PT Taspen merupakan Badan Usaha Milik Negara (BUMN) yang diberi tugas untuk mengelola Program Asuransi Sosial yang terdiri dari Program Dana Pensiun dan Tabungan Hari Tua (THT). Didirikan pada tanggal 17 April 1963 dengan nama Perusahaan Negara Dana Tabungan dan Asuransi Pegawai Negeri yang disingkat menjadi PN TASPEN. Pendirian PN Taspen di latar belakangi keinginan untuk meningkatkan kesejahteraan pegawai negeri dan keluarganya yang dirintis melalui Konferensi Kesejahteraan Pegawai Negeri pada tanggal 25-26 Juli 1960 di Jakarta. Sejak awal berdirinya TASPEN mengelola Program Tabungan Hari Tua bagi pegawai negeri dan sejak tahun 1987 mulai mendapat tugas untuk mengelola Program Pegawai Negeri Sipil (PNS) dengan demikian TASPEN telah 3 sepenuhnya mengelola Program Asuransi Sosial sesuai PP 25 Tahun 1981 yaitu Asuransi Sosial Pegawai Negeri Sipil termasuk Dana Pensiun dan THT. Selain mengelola Program Asuransi Sosial yang kepesertaannya bersifat wajib (compulsory) bagi PNS, saat ini TASPEN juga mengelola program THT, THT Multiguna dan THT Ekaguna untuk pegawai BUMN/BUMD yang kepesertaannya bersifat sukarela (voluntary).

\subsubsection{Bagian yang terkait dalam Sistem Akuntansi Pengeluaran Kas pada PT. Taspen (persero) Kantor Cabang Manado}

1. Kepala Bidang Layanan dan Manfaat

Bertanggungjawab atas pengelolaan dan pengendalian serta menjamin perhitungan hak telah sesuai dengan ketentuan yang berlaku dengan baik dengan baik 
2. Bidang Kas dan Verifikasi SPJ

Menjamin ketersediaan dana yang cukup untuk membayar kewajiban kepada peserta tepat waktu dan memverifikasi SPJP serta meningkatkan Time Value Of Money Perusahaan.

3. Bidang Administrasi Keuangan

Menjamin tersajinya Laporan Keuangan sesuai dengan standar kebijakan Akuntansi Perusahan yang berpedoman pada Pedoman Standar Akuntansi Keuangan (PSAK) serta peraturan perundangan yang berlaku untuk kepentingan Stakeholder.

4. Bidang Umum dan SDM

Bertanggungjawab mengelola, mengendalikan, dan menjamin kegiatan administrasi personalia perusahaan telah dilakukan dengan baik dan benar sesuai denagn ketentuan perusahaan yang berlaku serta menjamin terselenggaranya kegiatan administrasi aktiva dan sosialisasi perusahaan sehingga dapat diketahui oleh peserta secara menyeluruh terhadap citra perusahaan PT Taspen (Persero) dengan baik dan benar.

4.2.3. Dokumen yang digunakan dalam Sistem Akuntansi Pengeluaran Kas pada PT. Taspen (persero) Kantor Cabang Manado

1. Lembar Penelitian SPP Klim

2. Voucher Klim

3. Lembar Perhitungan

4. Slip Pengiriman Uang

5. Rekapitulasi Pembayaran NON - DAPEM

4.2.4. Catatan yang digunakan dalam Sistem Akuntansi Pengeluaran Kas pada PT. Taspen (Persero) Kantor Cabang Manado

1. Jurnal Pengeluaran Kas

2. Catatan Laporan Pengeleuaran atas Cek

4.2.5. Prosedur - prosedur yang membentuk Sistem Akuntansi Pengeluaran Kas pada PT. Taspen (persero) Kantor Cabang Manado

1. Prosedur Pengeluaran Kas dengan Cek yang Memerlukan Permintaan Cek.

2. Prosedur Permintaan Cek

3. Prosedur Pembuatan Bukti Kas Keluar

4. Prosedur Pembayaran Kas

5. Prosedur Pencatatan Pengeluaran Kas

\subsection{Pembahasan}

4.2.1. Analisis Sistem Akuntansi dan Prosedur Pembayaran Klaim JKM (Jaminan Kematian) PT. Taspen (Persero) KC Manado

A. Bagian yang terkait dalam Sistem Akuntansi Pengeluaran Kas pada PT. Taspen (persero) Kantor Cabang Manado

Bagian yang terkait dalam Sistem Akuntansi Pengeluaran Kas pada PT. Taspen (persero) Kantor Cabang Manado yaitu bidang pelayanan, seksi kas, seksi administrasi keuangan, bidang keuangan, dan seksi dosir. Fungsi yang terkait dalam sistem akuntansi pengeluaran kas pada PT. Taspen (persero) Kantor Cabang Manado mempunyai tugas dan wewenang yang sama dengan penjelasan tugas dan wewenang dalam teori.

Tugas dan wewenang setiap bagian yang terkait dalam PT. Taspen (persero) Kantor Cabang Manado yaitu bidang pelayanan yang bertugas untuk mengajukan permintaan pembayaran peserta, membuat Lembar Penelitian SPP Klim, menyerahkan Lembar Penelitian SPP Klim tersebut kepada bagian akuntansi untuk dipakai sebagai dasar permintaan cek. Bidang pelayanan juga bertanggung jawab untuk membuat Voucher Klim Program JKM dan Lembar Perhitungan untuk diserahkan ke seksi administrasi keuangan setelah diotorisasi oleh Kepala Bidang 
Pelayanan. Tugas dan wewenang bidang pelayanan kurang lebih sama dengan tugas dan wewenang fungsi yang memerlukan pengeluaran kas pada teori yaitu mengajukan permintaan cek.

Seksi kas pada PT. Taspen (persero) Kantor Cabang Manado mempunyai tugas dan wewenang yang sama dengan fungsi kas yang dijelaskan pada teori yaitu mengisi cek, memintakan otorisasi atas cek, dan mengirimkan cek kepada mitra bayar yang bekerjasama dengan perusahaan PT. Taspen (persero) Kantor Cabang Manado.

Seksi administrasi keuangan pada PT. Taspen (persero) Kantor Cabang Manado mempunyai tugas dan wewenang yang sama dengan fungsi akuntansi yang dijelaskan pada teori yaitu memintakan otorisasi kepada seksi kas dalam mengeluarkan cek sebesar yang tercantum dalam dokumen tersebut. seksi ini juga bertanggung jawab untuk verifikasi kelengkapan dan kesahan dokumen pendukung yang dipakai sebagai dasar pembuatan bukti kas keluar. Bidang keuangan mempunyai tugas dan wewenang yang sama dengan fungsi pemeriksaan intern yang dijelaskan pada teori yaitu melakukan perhitungan kas secara periodik dan mencocokkan hasil perhitungannya dengan saldo kas menurut catatan akuntansi.

PT. Taspen (persero) Kantor Cabang Manado juga mempunyai satu bidang yang tidak dijelaskan pada teori yaitu seksi dosir. Seksi dosir bertanggung jawab dalam pengarsipan dokumen-dokumen pendukung yang dipakai sebagai dasar pembuatan bukti kas keluar.

B. Dokumen yang digunakan dalam Sistem Akuntansi Pengeluaran Kas pada PT. Taspen (persero) Kantor Cabang Manado

Dokumen yang digunakan dalam Sistem Akuntansi Pengeluaran Kas pada PT. Taspen (persero) Kantor Cabang Manado meliputi Lembar Penelitian SPP Klim, voucher klim, lembar perhitungan, slip pengiriman uang, rekapitulasi pembayaran pensiun NON-DAPEM. Dalam teori dokumen yang digunakan dalam Sistem Akuntansi Pengeluaran Kas yaitu bukti kas keluar, cek, dan permintaan cek.

Dokumen awal yang digunakan dalam Sistem Akuntansi Pengeluaran Kas pada PT. Taspen (persero) Kantor Cabang Manado yaitu Rekapitulasi Pembayaran Pensiun non-dapem. Rekapitulasi pembayaran pensiun non-dapem merupakan dokumen yang digunakan sebagai bukti kas keluar sebesar yang tercantum dalam dokumen tersebut. Dokumen awal yang digunakan dalam pengeluaran kas diatas sama dengan yang dijelaskan pada teori. Bukti pembayaran yang digunakan dalam transaksi pengeluaran kas pada PT. Taspen (persero) Kantor Cabang Manado adalah slip pengiriman uang yang kegunaannya adalah sebagai bukti pembayaran atau transfer kepada Bank-bank yang bekerja sama dengan PT. Taspen (persero) Kantor Cabang Manado. Bukti kas keluar pada PT. Taspen (persero) Kantor Cabang Manado yaitu Lembar penelitian SPP klim ini dibuat oleh bidang pelayanan, dokumen ini digunakan sebagai dasar perhitungan hak, dari dokumen ini juga perusahaan bisa mengetahui data mengenai nama peserta, alamat peserta, nomor rekening peserta, kantor bayar SPP, dan lain sebagainya. Voucher Klim ini dibuat oleh bidang pelayanan, dokumen ini digunakan sebagai dasar permintaan cek, dari dokumen ini juga perusahaan bisa mengetahui jumlah hak peserta yang akan dibayarkan. Lembar Perhitungan dan Tanda Terima dibuat oleh bidang pelayanan, dokumen ini digunakan sebagai dasar permintaan cek, dari dokumen ini juga perusahaan bisa mengetahui jumlah hak peserta yang akan dibayarkan.

C. Catatan yang digunakan dalam Sistem Akuntansi Pengeluaran Kas pada PT. Taspen (persero) Kantor Cabang Manado.

Catatan yang digunakan pada PT. Taspen (persero) Kantor Cabang Manado antara lain jurnal pengeluaran kas dan catatan laporan pengeluaran atas cek. Dalam 
teori catatan yang digunakan yaitu jurnal pengeluaran kas dan register cek. Jurnal pengeluaran kas digunakan untuk mencatat pengeluaran kas yaitu berdasarkan dokumen-dokumen yang digunakan sebagai permintaan cek yang telah dicap "LUNAS" oleh seksi kas. Catatan laporan pengeluaran atas cek digunakan untuk mencatat cek-cek yang digunakan dalam pengeluaran kas.

D. Prosedur-prosedur yang membentuk Sistem Akuntansi Pengeluaran Kas pada PT. Taspen (persero) Kantor Cabang Manado

Prosedur-prosedur yang ada pada PT. Taspen (persero) Kantor Cabang Manado sudah sama dengan yang dijelaskan pada teori. Prosedur-prosedur dalam teori meliputi prosedur pengeluaran kas dengan cek yang memerlukan permintaan cek, prosedur permintaan cek, prosedur pembuatan bukti kas keluar, prosedur pembayaran kas, prosedur pencatatan pengeluaran kas, sedangkan prosedur-prosedur pada PT. Taspen (persero) Kantor Cabang Manado yaitu antara lain:

1. Prosedur Pengeluaran Kas dengan Cek yang Memerlukan Permintaan cek

Prosedur ini dilaksanakan oleh bidang pelayanan yang bertujuan untuk melayani peserta, membuat lembar penelitian SPP klim, voucher klim, dan lembar perhitungan sebagai dasar permintaan cek yang diperlukan untuk pembuatan bukti kas keluar. Bukti kas keluar dipakai sebagai perintah kepada seksi kas untuk membuat cek atas bukti kas keluar tersebut.

2. Prosedur Permintaan cek

Prosedur ini dilakukan oleh bidang pelayanan untuk melakukan perhitungan atas hak peserta pensiun dan membuat lembar perhitungan hak, kemudian mencetak voucher klim. Lembar perhitungan hak dan voucher klim dimintakan otorisasi dari kepala bidang pelayanan dan dikirimkan ke seksi administrasi keuangan

3. Prosedur Pembuatan Bukti Kas Keluar

Prosedur ini dilaksanakan oleh seksi administrasi keuangan untuk membuat bukti kas keluar atas dokumen-dokumen pendukung berdasarkan permintaan cek. Bukti kas keluar ini berfungsi sebagai perintah kepada seksi kas untuk mengisi cek sebesar jumlah rupiah yang tercantum pada dokumen-dokumen tersebut.

4. Prosedur Pembayaran Kas

Prosedur ini dilakukan oleh seksi kas untuk mengisi cek, memintakan otorisasi atas cek, dan mengirimkan cek tersebut kepada bank-bank dan kantor pos yang bekerjasama dengan perusahaan.

5. Prosedur Pencatatan Pengeluaran Kas

Prosedur ini dilakukan oleh seksi administrasi keuangan untuk mencatat pengeluaran kas dalam jurnal pengeluaran kas.

Dari hasil penelitian dan pembahasan terhadap Sistem Akuntansi Pengeluaran Kas dan Prosedur Pembayaran Klaim Jaminan Kematian pada PT. Taspen (Persero) Cabang Manado telah efektif dan telah sesuai dengan teori. Hal ini dibuktikan dengan :

1. PT. Taspen (persero) Kantor Cabang Manado sudah melibatkan bagian-bagian yang bertanggung jawab dalam tugasnya sehingga dapat dilakukan pengecekkan antar bagian yang terkait. Bagian-bagian tersebut meliputi bidang pelayanan, seksi kas, seksi administrasi keuangan, bidang keuangan, dan seksi dosir.

2. Dokumen-dokumen yang digunakan dalam sistem akuntansi pengeluaran kas pada PT. Taspen (persero) Kantor Cabang Manado meliputi lembar penelitian SPP klim, voucher klim program pensiun, lembar perhitungan, slip pengiriman uang, rekapitulasi pembayaran pensiun NON-DAPEM.

3. Catatan yang digunakan dalam sistem akuntansi pengeluaran kas pada PT. Taspen (persero) Kantor Cabang Manado yaitu jurnal pengeluaran kas, catatan laporan pengeluaran atas cek. Catatan yang digunakan didistribusikan dengan baik yaitu 
informasi dalam catatan tersebut didistribusikan sesuai dengan kebutuhan setiap bagian sehingga setiap bagian yang terkait dapat melihat catatan tersebut sesuai dengan wewenangnya.

4. Prosedur yang membentuk sistem akuntansi pengeluaran kas pada PT. Taspen (persero) Kantor Cabang Manado terdiri dari prosedur pengeluaran kas dengan cek yang memerlukan permintaan cek, prosedur permintaan cek, prosedur pembuatan bukti kas keluar, prosedur pembayaran kas, prosedur pencatatan engeluaran kas.

5. PT. Taspen (persero) Kantor Cabang Manado telah mempunyai bagan alir sistem akuntansi pengeluaran kas yang telah ditetapkan sesuai dengan tanggung jawab dan wewenang masing-masing bagian.

Terjadinya keterlambatan dalam melakukan pembayaran dikarenakan adanya kekurangan berkas pada saat bidang pelayanan melakukan penelitian terhadap data peserta, ada beberapa peserta yang tidak memenuhi syarat yang ditetapkan sehingga berkas tersebut di kembalikan kepada keluarga peserta atau ahli waris untuk melengkapi syarat yang telah ditetapkan sampai data tersebut siap diproses sehingga dalam hal ini pembayaran jaminan kematian mengalami ketertundaan. Berikutnya dalam melakukan pembayaran jaminan kematian mengalami keterlambatan dikarenakan data peserta dicurigai tidak benar sehingga karyawan bidang pelayanan harus teliti dalam menganalisis data satu per satu yang menyebabkan terjadi keterhambatan dalam melakukan proses pembayaran jaminan kematian.

\section{KESIMPULAN DAN SARAN}

\subsection{Kesimpulan}

Berdasarkan hasil penelitian yang dilakukan penulis pada PT. Taspen (persero) Kantor Cabang Manado maka dapat diambil kesimpulan bahwa Sistem Akuntansi dan Prosedur Pembayaran Klaim Jaminan Kematian yang diterapkan pada PT. Taspen (persero) Kantor Cabang Manado telah efektif karena telah sesuai dengan teori yang ada. Penulis membandingkan teori Sistem Akuntansi Pengeluaran Kas (Mulyadi, 2014:513) dengan Sistem Akuntansi dan Prosedur Pembayaran Kalim JKM (Jaminan Kematian) yang membentuk Pengeluaran Kas yang diterapkan pada PT. Taspen Kantor Cabang Manado.

\subsection{Saran}

1. Sistem Akuntansi dan Prosedur Pembayaran Klaim Jaminan Kematian pada PT. Taspen (persero) Kantor Cabang Manado sudah memadai dan harus dipertahankan oleh perusahaan dengan cara melakukan pengawasan terhadap pelaksanaan sistem akuntansi dan prosedur pembayaran JKM agar sistem yang ada di perusahaan dapat tetap berjalan dengan baik.

2. PT. Taspen (persero) Kantor Cabang Manado sebaiknya sebelum berkas peserta masuk pada bagian bidang pelayanan sebaiknya diteliti terlebih dahulu untuk mengetahui apakah berkas tersebut sudah lengkap dan siap di proses atau belum.

\section{DAFTAR PUSTAKA}

Darmawi, Herman. 2004. Manajemen Asuransi. Jakarta: PT. Bumi Aksara.

Horngren, Charles T., dan George Foster., dan Srikant Datar. 1993. Cost Accounting: A Managerial Emphasis. 8th Edition. Prentice - Hall International Inc.

Indrawan, Poppy Yaniawati. 2014. Metodologi Penelitian. Penerbit Refika Aditama. Jakarta. Iniyati. (2013), "Evaluasi Sistem Akuntansi Pengeluaran Kas Pada PT. Taspen (Persero) Kantor Cabang Yogyakarta”, Universitas Negeri Yogyakarta, Fakultas Ekonomi.

Kaligis, Ilat, dan Pontoh. (2015), "Analisis Penerapan Sistem Pengendalian Intern Kas Pada Dinas Pendapatan Daerah Kota Bitung".

Mulyadi. 2001. Akuntansi Manajemen: Konsep, Manfaat dan Rekayasa. Edisi Ketiga. Jakarta: Salemba Empat. 
Mulyadi. 2008. Sistem Akuntansi. Jakarta: Salemba Empat.

Mulyadi. 2013. Sistem Akuntansi. Jakarta: Salemba Empat.

Mulyadi. 2014. Sistem Akuntansi. Yogyakarta: Salemba Empat.

Rosalie, Budiarso. (2017), “Analisis Pengakuan Pendapatan dan Beban Menurut PSAK No.

28 Pada PT. Asuransi TRI Pakarta Cabang Manado".

Sugiyono. 2010. Metode Penelitian Kuantitatif Kualitatif \& RND. Bandung : Alfabeta.

Sugiyono. 2013. Metode Penelitian Pendidikan (pendekatan kuantitatif, kualitatif, dan R\&D). Bandung : Alfabeta.

Weygandt, Jerry., Kieso, E Donald.,Kimmel, D Paul. 2007. Pengantar Akuntansi Buku I. Edisi Tujuh. Alih Bahasa oleh Ali Akbar Yulianto. Wasifah. Rangga Handika. Salemba Empat. Jakarta.

www.taspen.co.id 